\title{
ECOLOGICAL ASPECTS OF SUSTAINABLE AGRICULTURE IN BULGARIA (ON THE BASIS OF SILISTRA AND PLOVDIV REGIONS)
}

\author{
Albena Miteva, Zornitsa Stoyanova \\ University of National and World Economy, Natural Resources Economics Department, \\ Studentski grad, Sofia 1700, Bulgaria \\ zori_stojanowa@yahoo.de
}

\begin{abstract}
In recent years the concept of sustainable development and related sustainable agriculture has come under wide public debate. The purpose of the paper is on the basis for sustainable agriculture and analysis of agricultural holdings influence on environment in Bulgaria to suggest trends for solving some ecological problems. The paper comprises three parts. In the first part a theoretical review of sustainable development and agriculture concept is made. The second part of the paper analyzes ecological aspects of sustainable agriculture in Bulgaria. In the third part suggestions for overcoming some ecological problems are made.
\end{abstract}

Key words: sustainable development; ecology; sustainable agriculture

\section{ЕКОЛОШКИ АСПЕКТИ НА ОДРЖЛИВОТО ЗЕМЈОДЕЛСТВО ВО БУГАРИЈА (ВРЗ БАЗА НА РЕГИОНИТЕ СИЛИСТРА И ПЛОВДИВ)}

\begin{abstract}
Последниве години концептот на одржлив развој и соодветното одржливо земјоделство стана предмет на широка јавна дебата. Целта на овој труд е, врз база на одржливото земјоделство и анализа на влијанието на земјоделските стопанства врз животната средина во Бугарија, да се предложат трендови за решавање на некои еколошки проблеми. Трудот содржи три дела. Во првиот дел е извршен теоретски преглед на одржливиот развој и земјоделскиот концепт. Вториот дел од трудот ги анализира еколошките аспекти на одржливото земјоделство во Бугарија. Во третиот дел се дадени предлози за надминување на некои еколошки проблеми.
\end{abstract}

Клучни зборови: одржлив развој; екологија; одржливо земјоделство

\section{THEORETICAL ASPECTS OF SUSTAINABLE AGRICULTURE}

The UN Conference "Human Environment" held in Stockholm in 1972, Brundland Commission Report in 1987, the accepted principles by the UN Conference in Rio de Janeiro in 1992, Johannesburg Summit on Sustainable Development in 2002 put on a wide public debate the concept of Sustainable Development $/ \mathrm{SD} /$ and linked with it Sustainable Agriculture /SA/. The role of agriculture for realizing of economic, ecological and social criteria for SD depends on overall influence of agricultural producers and the conditions of their agricultural holdings.
The significance of agricultural holdings for $\mathrm{SD}$ is predetermined by the relative significance of farming and non-farming activities for regional economics, by the approved good practices for agricultural production, by the provision of healthy food to population, landscape, quality of environment and biodiversity preservation.

The purpose of the paper is on the basis of sustainable agriculture and analysis of agricultural holdings influence on the environment in Bulgaria to suggest trends for solving some ecological problems.

The role of agriculture is depicted in the context of SD formulated as per European Agri- 
cultural Convention. In the Convention it is stated that "agriculture should be accepted as a key sector for rural people and communities' welfare." Agriculture and forests are defined as a "primary sector" which leads on the road of SD. In the Convention in the approach concerning the future CAP the economic, social and ecological stability are considered, which should secure continuity of agricultural production and occupancy in Europe. They should protect natural resources and offer a prospect for development of young agricultural producers. Some authors state that agriculture itself is changing and obtains sustainable character. For Pretty (1997) sustainable agriculture is not a defined constant number of practices and policies, but it is a "process of social learning and common research, starting with the assets mainly of local communities and offering targets and indicators for measuring the progress". The author suggests series of steps for obtaining sustainability, passing through enhancement of economic and ecological stability, implementation of integrated regenerative production technologies and coming to reformulation of community targets taking into consideration the fact that creators of the sustainable practices are farmers and local villagers. The activities of persons and different organizations introduce different practices via which the targets realization become closer. In 2003, the same author defines the role of agriculture as a contributor for $\mathrm{SD}$, preserving the environment, creates sustainable viability of rural regions and alleviates rural poverty.

Other authors (Kenny, 1989) define sustainable agriculture as "agricultural systems, which are ecological, profitable productive and maintain the social structure of rural community." Analogical is Becker's (1997) opinion, who defines agriculture as sustainable when it is "ecologically directed, economically viable, socially equitable, culturally adequate and is based on a holistic scientific approach.”.

The position of Bulgarian scientists - as per Hadjieva (2004) is similar: "Sustainable agriculture is economically effective, ecologically stable and socially responsible". According to the author sustainable agriculture is competitive creating products with high quality, implementing productive methods which preserve the environment, saving natural resources and improving quality of life of agricultural producers and of consumers of their products. This definition fully encompasses the role of agriculture for $\mathrm{SD}$, because stress on its influences not only in economic and ecological aspects, but in social aspects as well and thus fully reflects the targets of SD.

Some authors such as Velchev, Valev, Borisov (1997) define sustainable agriculture as: "pursuit of reaching the potentially possible for a concrete agricultural region yields with high biological values of the products via suitable agroequipment which guarantees the receipt of the best economic results in market conditions with simultaneously preservation and enhancement of soil fertility and environmental protection". The definition stresses the sustainability dependency on agro-technology via which economic and ecological effect is obtained, omitting the social aspect.

Part of the definitions cover many aspects, examining SD not only from economic and ecological point of view, but combine other aspects such as social, biological, technological and others. Some of them encompass only one of several of its aspects. Besides this, these positions allow the conclusion, to be drawn that sustainable agriculture is linked not only with the productive system itself, but with the development of the region as well.

In the paper are analyzed some aspects of the influence of agriculture on SD of rural regions and special attention is drawn to those with ecological aspect.

\section{INFLUENCE OF AGRICULTURE ON ENVIRONMENT IN BULGARIA}

The concept of SD in ecological aspect presupposes sustainable use of natural resources. Agriculture is a peculiar economic sector, because its activities are realized in and via environment and between 35 to $50 \%$ of the territory is managed by agricultural producers. The natural environment secures the main resources for agriculture, but agriculture influences and changes the environment itself as well. Agriculture's main target is to produce food stuffs and due to this has a negative impact on some environmental elements. On the other hand a large part of the valuable environment in rural regions is a result from the implemented agricultural practices allowing the creation and preservation of unique landscape, rich variety of animal species and plants which depend on its functioning. 
There is a narrow, complex and dynamic relation between agriculture and environment. Agricultural practices, the level of intensification, the quality of resource inputs define the character of emerging ecological problems and its influence on the environmental quality.

As a whole the changes in Bulgarian agriculture during the last 15 years led to a decrease in artificial fertilizers and chemicals use, to holdings fragmentation and restoration of some of the natural elements in agricultural landscape which had a positive impact on biodiversity. Simultaneously with this some processes are manifested which influence negatively on biodiversity - abandoned agricultural land, stop cutting the meadows, conversion of valuable form environmental point of view land (such meadows, pasture-grounds) in cultivated land, use of some inappropriate agricultural techniques, uncontrolled gathering and destruction of plants varieties and animal species. On the other hand the threats to coastal ecosystems are water pollution, uncontrolled catch and new species introduction.

The main problems in terms of water quality in our country are pollution from inhabited places and agricultural holdings, existence of equipment for manure storage non-meeting EU requirements, lack of a sewerage system in many villages and other. During the Agricultural Holdings Census in 1993 it was identified that only 528 holdings had a specially protected place for manure storage and 484836 had at their disposal only ordinary manure-heap. This fact stresses the necessity to undertake special measures for helping farmers to build safe manure-heaps.
In Bulgaria there are facts supporting the idea that the process of desertification takes place in the country. The reasons are complex and are linked with the processes of degradation such as soil erosion in all forms, acidification, soil salting, pollution and other.

More than $60 \%$ of the territory of the country is subject to erosion of a different degree. The distribution of risk from water erosion and respective losses depicts the prevailing affected plots with losses over $5 \mathrm{t} / \mathrm{ha}$ and plots with from moderate to high risk of erosion.

Despite these negative trends the interest of farmers for developing activities preserving the environment increases. In October 2006 Measure 1.3. „Development of agricultural activities, aimed at environment protection" of the SAPARD program started working. The total number of submitted projects is 208 (Table 1), from which 201 projects were approved and 7 were rejected. The prevailing part of the approved projects were from the activity „Organic farming” - 111, 80 were from the activity „Protection of endangered local breed”, 9 were from „Management of semi-natural habitats" activity and 1 from the activity „Support of anti-erosion activities". The support for activities linked with the use of the agricultural land in non-favored regions and preservation of the good agricultural and ecological conditions in these regions will lead to a decrease in the abandoned agricultural land and erosion in these regions. The number of applicants shows a gradual increase in the interest towards activities aimed and environment preservation.

T a b le 1

Number of approved and rejected projects under Measure 1.3. "Development of agricultural activities aimed at environment protection" for the period from 1.1.2007 to 31.12.2007

\begin{tabular}{lccrr}
\hline \hline \multirow{2}{*}{ Activity } & \multicolumn{2}{c}{$\begin{array}{c}\text { Number of projects } \\
\text { Approved financial help } \\
\text { (BGN) }\end{array}$} \\
\cline { 2 - 5 } & Rejected & Approved & Total amount & From EC \\
\hline Organic farming & 4 & 111 & 5148038,00 & 3861028,50 \\
Endangered local breeds & 0 & 80 & 4122034,00 & 3091525,50 \\
Management of semi natural habitats & 2 & 9 & 654662,00 & 490996,50 \\
Support for anti-erosion practices & 1 & 1 & 7630,00 & 5722,50 \\
Total & 7 & 201 & 9932364,00 & 7449273,00 \\
\hline \hline
\end{tabular}

Source: Ministry of Agriculture and Food, 2008, Agrarian Report 2007 
The influence of agricultural holdings on ecological aspects of SD in the country might be assessed as well through the number of holdings performing non-agricultural activity. This could be explained on the one hand by the fact of the holdings via diversification of their activity influence in economic and social terms creating the added value and occupancy. On the other hand via sustainable use of resources, integration of ecological requirements for production of certain products, they influence ecological terms as well.

In 2003 according to Census data non-agricultural activities were registered by only $4.41 \%$ of agricultural holdings (Table 2) and by $63 \%$ of the registered agricultural producers. The biggest is the spreading of agricultural holdings which process food stuffs $(47.33 \%)$, followed by producers offering mechanized services (33.54\%).

Data from a survey of agricultural holdings executed in 2005 depicted that in absolute terms the spreading of agricultural holdings active in non-agricultural activities decreased. In 2005 the Statistical Institute monitored five from nine nonagricultural activities and for four of them a decrease in the number of holdings executing them was noticed. The decrease in fish-breeding is significant with more than $80 \%$ and in crafts - more than $40 \%$. The changes in wood processing and mechanized services are relatively smaller. The change is in positive direction only for agricultural producers who develop rural tourism, but the increase is only $8.3 \%$.

Table 2

\section{Agricultural holdings per type non-agricultural activity}

\begin{tabular}{|c|c|c|c|}
\hline \multirow{2}{*}{$\begin{array}{l}\text { Types non-agricultural } \\
\text { activities }\end{array}$} & \multicolumn{2}{|c|}{$\begin{array}{c}\text { Number of } \\
\text { agricultural holdings }\end{array}$} & \multirow{2}{*}{$\begin{array}{c}\text { Structure } \\
(\%)\end{array}$} \\
\hline & 2003 & 2005 & \\
\hline Mechanized services & 9684 & 7987 & 33,54 \\
\hline Processing of food-stuffs & 13665 & - & 47,33 \\
\hline Wood-processing & 115 & 74 & 0,4 \\
\hline Rural tourism & 338 & 366 & 1,18 \\
\hline Crafts & 290 & 173 & 1,00 \\
\hline Fish-breeding & 1064 & 177 & 3,68 \\
\hline Production of renewable energy & 66 & - & 0,23 \\
\hline Other activities & 3647 & - & 12,64 \\
\hline Total & 28869 & - & 100,0 \\
\hline Relative share of holdings (\%) & 4,41 & - & - \\
\hline
\end{tabular}

Source: Ministry of Agriculture and Food, 2005, Results from the Census of Agricultural Holdings in Bulgaria in 2003.
The attitude of agricultural producers for development of non-agricultural activities is a precondition for a more fully use of resources, for diversification of rural regions economics and for their sustainable development. Due to these reasons the expected future behavior and intentions of agricultural producers were investigated in Bulgaria via conduction of a survey among more than 100 agricultural holdings in Plovdiv and Silistra regions. ${ }^{1}$ When choosing the objects of the investigations the following criteria were used: agricultural holdings with more than 5 year period of existence, to be registered as agricultural producers, to develop other activities linked with agriculture or to possess and manage other business, to be active in the search for information and knowledge for CAP requirements.

The data from the conducted interviews depict a high degree of interest of agricultural producers towards the multifunctional activity, because $90 \%$ of the interviewed people indicated at least one activity which they have intention to develop.

Opportunities for a better use of resources are expressed through the data of Table 3, which illustrate the spreading of interviewed producers depending on their desire to develop a multifunctional activity. Data depict the difference in the relative shares of the people who wish to develop one or two of the activities. In the Silistra region, the spreading of opinions is between people who wish to develop 2 activities $-30 \%$, and those who want to develop only one multifunctional activity more than $52 \%$. The situation in the Plovdiv region is different, where $43 \%$ from the interviewed people expressed desire to develop two activities and over $26 \%$ wish to be active with only one.

Table 3

\section{Distribution of interviewed producers according to their intentions for development of multifunctional activities (\%)}

\begin{tabular}{lcccc}
\hline \hline Municipalities & 3 & 2 & 1 & Will not develop \\
& activities & $\begin{array}{c}\text { activities } \\
\text { activity }\end{array}$ & \\
\hline Silistra & 5 & 30 & 52,5 & 12,5 \\
Plovdiv & 21,5 & 43 & 26,5 & 8,5 \\
Total & 15 & 38 & 37 & 10 \\
\hline \hline
\end{tabular}

${ }^{1}$ The survey was conducted within the project "Prerequisites and conditions for transition to a multifunctional model of agriculture", funded by UNWE (university scintific research). 
The preference of agricultural producers to different types of non-agricultural activities which they would like to develop is presented in Table 4. In 2003 every fifth (21\% from the interviewed) has intention to develop rural tourism, and $17 \%$ intend to provide mechanized services or to make direct sales of food-stuffs. On the third place with $15 \%$ are those who choose to process agricultural products. Relatively smaller is the interest of agricultural producers in activities like fish-breeding, provision of services and other.

\section{Table 4}

\section{Intentions of producers to develop different non-agricultural activities (number)}

\begin{tabular}{lccc}
\hline \hline Types of activities & $\begin{array}{c}\text { Plovdiv } \\
\text { region }\end{array}$ & $\begin{array}{c}\text { Silistra } \\
\text { region }\end{array}$ & Total \\
\hline Not expressed & 5 & 5 & 10 \\
Rural tourism & 14 & 7 & 21 \\
Mechanized services & 14 & 3 & 17 \\
Direct sales of food-stuffs & 9 & 8 & 17 \\
Processing of agricultural food-stuffs & 5 & 10 & 15 \\
Processing of agricultural non-food & & & \\
stuffs & 2 & 1 & 3 \\
Fish-breeding & 2 & 1 & 3 \\
Services & 1 & 2 & 3 \\
Wood processing & 5 & - & 5 \\
Crafts & 3 & 1 & 4 \\
Other & - & 2 & 2 \\
Total & 60 & 40 & 100 \\
\hline \hline
\end{tabular}

A survey was conducted for the expected changes in the development of agricultural holdings and the attitudes and future intentions of producers among experts from the Regional Department "Agriculture and Forestry" in Silistra and Plovdiv.

In the Silistra region experts evaluated positively the role of agriculture for the development of the region. The highest are the values for its positive role for landscape preservation (20\% fully accept the answer and $80 \%$ - to some extent), followed by its role for enhancing environment quality (20\% fully accept the answer and 60 $\%$ - to some extent). The positive role of agriculture for improving rural region viability via securing income and occupancy of rural population is ranked on the third place. This opinion is shared by $60 \%$ from the interviewed people from them
$20 \%$ fully support this idea and $40 \%$ - to some extent.

The role of agriculture for protecting animal wealth was assessed negatively. This is supported by $60 \%$ from the interviewed people but they marked the answer - "to some degree". $20 \%$ of the experts are on a contrary opinion and the rest did not express their opinion.

The experts in Silistra do not support the statement that agricultural producers realize their possibilities to influence the quality of environment and to be able to environmental manages ( 40 $\%$ did not agree at all and $20 \%$ - to some extent). $40 \%$ of the interviewed experts are on a contrary opinion but expressed via the rank "to some degree".

There is a full consensus for the necessity of additional education of agricultural producers in order to be able to execute successfully their role for protecting the environment and preserving the biodiversity.

The experts from the Plovdiv region assess positively the role of agriculture for the development of the region. The highest is the support for the statement that agriculture has a positive role for increasing the rural region viability, securing income and occupancy. All interviewed experts agree with the statement, $66,7 \%$ from them fully accept it and 33,3\% to some extent.

The understanding that agriculture has a positive role for improving environmental quality is on the next place (with $100 \%$ as well). $33,3 \%$ from the interviewed experts fully support this idea and $66,7 \%$ to some extent.

The statements about the positive role of agriculture for the landscape preservation and animal wealth protection enjoy high support - 83,3\% from the experts agree with them, whereas $16,7 \%$ of the experts did not express their opinion.

The experts did not agree with the statement that agricultural producers fully realize their possibilities to influence the environmental status and to be environmental managers. This statement is supported by only $33 \%$ from the interviewed people and the rank "to some extent" was chosen. The appraisal for the next statement - for the necessity of additional education of agricultural producers in the area of environmental management, is directly linked with this opinion. All interviewed experts agree with it, $83.3 \%$ - fully, and $16.7 \%$ - to some extent. 


\section{MAIN CONCLUSIONS AND SUGGESTIONS}

On the basis of the analysis of agricultural holdings influence on environment and attitudes of agricultural producers for development of nonagricultural activities the following general conclusions could be made:

- The number of applicants to receive financial support under the state measures aimed at environmental protection shows the increasing interest of agricultural producers towards such activities.

- The comparison between the number of agricultural holdings with multifunctional activity depicts that active agricultural holdings are highly interested in such activities. A high degree of interest was noticed by agricultural producers towards multifunctional activities and a large part of the interviewed wish to develop one or two nonagricultural activities - respectively 37 and $38 \%$. A relatively small part of them - only $15 \%$ wish to develop three activities and only $10 \%$ do not have desire to develop non-agricultural activities.

- The role of agriculture for development of rural regions is assessed positively by agricultural producers. The highest is the score for the role of agriculture for the landscape preservation and for its role for increasing the rural region viability via securing income and occupancy for rural population.

- Agricultural producers realize their opportunities to influence on environment and to become environmental managers to some extent.

To overcome some of the above mentioned problems and strengthen the positive influence of agriculture on ecological aspects of SD the following activities could be executed:

- Modernization of agricultural holdings in terms of technologies, managerial and organizational practices and decrease of production expenses. For this agricultural producers should make use of the funds envisaged in the National Strategic Plan 2007-2013. Its first target is modernization of technologies and implementation of modern practices for land and forest management, innovations encouragement, economic activities diversification, farms modernization in terms of their influence on environment, adaptation of holdings' structure and land ownership. For realizing this strategic goal $42 \%$ of its budget is envisaged. Moreover, agricultural producers might receive financing under the Measure "Adding value to agricultural and forest products" from the "Development of rural regions" program, whose aim is to improve the economic situation of enterprises from food-processing and forestry sectors via better use of production factors. This will contribute to the environment protection via introduction of new products, processes and technologies.

- Development of abilities and transfer of knowledge for new technologies, renewable energy sources, products of organic farming, improvement of environmental managerial abilities. This could be realized via improvement of the business information environment. It is necessary to broaden the scope of the National Extension Service System and to create preconditions to inform agricultural producers and to implement the best production practices from the largest number of agricultural producers. In this direction the Measure "Consulting Services" with "Development of Rural Regions" program could be used, whose aim is to secure adequate level of technical and economic knowledge and abilities for business management, new technologies, products' safety and quality, sustainable use of natural resources, renewable energy sources and organic farming.

- Development of agricultural methods aimed at environment protection and compensation of producers from mountainous and other non-favored regions. The funds envisaged as per second goal from the "Strategy for development of rural regions in Bulgaria" for the period 2007-2013 are the opportunity to carry out this suggestion. The funds envisaged in it cover the above mentioned activities. This program encourages as well activities linked with biodiversity preservation, water protection, sustainable land and natural resources use via implementation of effective agricultural practices. For this Acquis $27 \%$ of the funds from the overall budget for the 3 Acquis of the program for the period from 2007 to 2013 are allocated. In order to develop agricultural activity in mountainous regions and to weaken their depopulation the compensation payments for maintaining the landscape and biodiversity could be used, as well as those payments allocated for preservation and sustainable use and development of land and other natural resources. The measure "Payment for natural limitations for farmers in mountainous regions" from the Program for Development of Rural Regions is elaborated to compensate the additional expenses and omitted income of agricultural pro- 
ducers due to the limitations for agricultural production in the respective region. With the compensation payment the lower farmers' income is not fully compensated.

- Encouragement to agricultural producers to invest in non-agricultural activities like rural tourism, production of energy from renewable sources and other with the aim to develop activities which protect the environment and limit the negative influence on nature. Support of investment in nonagricultural activities is envisaged in one of the measures of the Program for Development of Rural Regions. The idea is to finance projects linked with production of energy cultures, rural tourism, hunting tourism, fishing, consulting services and other.

The executions of the suggestions backed with the funds envisaged in some of the measures of the state support will be of considerable significance for restructuring and modernization of Bulgaria agriculture, solving some important ecological problems and increase of the agricultural sector role for making progress towards sustainable development, particularly in the ecological aspect.

\section{REFERENCES}

[1] Becker B. (1998): Sustainability Assessment: A Review of Values, Concepts, and Methodological Approaches, Issues in Agriculture 10, CGIAR, World Bank.

[2] European Agricultural Convention "Future of Rural Regions of Enlarged Europe" (2002).

[3] Doichinova J. et al. (2008): Предпоставки и условия за преход към мултифункционален модел на земеделие, УИ “Стопанство".

[4] Hadjieva et al. (2004): Въпроси и състояние на устойчивото развитие на земеделието.

[5] Kenny D. R. (1989): Toward a sustainable agriculture: need for clarification of concepts and terminology, American Journal of Alternative Agriculture, 4, 101-105.

[6] MAF (2005): Results from agricultural holdings Census in 2003.

[7] MAF (2006) National Strategic Plan for Rural Regions Development 2007-2013.

[8] MAF (2008) Agrarian Report 2007.

[9] National Startegy Plan for Rural Development 2007-2013 (2006).

[10] Pretty J. (1997): The sustainable intensification of agriculture, National Resources Forum, 21, pp. 247-256.

[11] Pretty J., Hine R. (2007): What is sustainable agriculture?, University of Essex, Centre for Environment and Society Program for Rural Development.

[12] Velchev et al. (1997): Проблеми на устойчивото развитие и производството на екологично чиста продукция от зърнени култури, Селскостопанска наука, бр. 4-6. 
